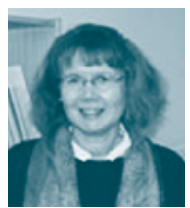

Ådel Bergland, førsteamanuensis, Diakonhjemmet Høgskole og Gruppe for eldreomsorgsforskning Institutt for sykepleievitenskap og helsefag Universitetet i Oslo

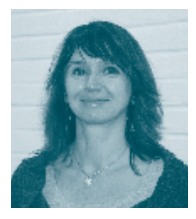

Olaug Vibe,

kvalitetssjef, Cathinka

Guldberg-senteret

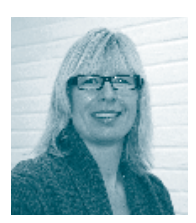

Nina Martinussen,

oversykepleier, Cathinka Guldberg-senteret

www.sykepleien.no

Les mer og finn litteraturhenvisninger på våre nettsider.

Søkeord:

) Sykehjem

Geriatri

- Arbeidsmiljø

Arbeidstid

> Identitet

sykepleierolle

\title{
Hvordan få sykepleiere til å se på sykehjem som en fremtidig arbeidsplass?
}

\author{
Økt tydelighet og anerkjennelse av sykepleiers rolle i sykehjem \\ kan bidra til at flere forblir i jobben.
}

E tilstrekkelig antall kvalifiserte sykepleiere er avgjørende for å sikre god kvalitet i sykehjem (1-3). Mange norske sykehjem erfarer at det er vanskelig å rekruttere og beholde sykepleiere (3). Artikkelen presenterer prosjektet «Kunsten å bli på sin post», som er gjennomført ved et sykehjem i Oslo. Hensikten var å identifisere forhold som sykepleiere mente var av betydning for å beholde sykepleiere i sykehjemmet.

\section{Litteraturgjennomgang}

I litteraturen beskrives to hovedkategorier av begrunnelser for å arbeide i sykehjem: Indre faktorer og ytre faktorer.«Ytre faktorer» er at jobben ligger i nærmiljøet, fleksible arbeidstider som kan tilpasses familiesituasjonen eller mangel på ledige jobber på sykehus (4, 5). «Indre faktorer» er ønske om å arbeide med eldre mennesker, basert på positive erfaringer med denne gruppen og/eller positive erfaringer fra sykehjem i studietiden $(4,6)$. Andre begrunnelser er store faglige utfordringer på grunn av beboernes komplekse og varierte sykdomsbilde, kontakten med og anerkjennelsen fra beboerne, ønske om å bidra til en best mulig livssituasjon for beboerne, samt kontinuitet i relasjonen med beboeren og pårørende (4-8). Forhold som oppfattes belastende er den store arbeidsmengden som gjør det vanskelig å opprettholde tilfredsstillende kvalitet på omsorgen, få sykepleiere og dermed et begrenset fagmiljø, å være alene om ansvaret for et stort antall beboere, å påføre kollegaer ekstra arbeidsoppgaver når beboere på andre avdelinger har behov for sykepleier, samt mye veiledning av ufaglærte (4-6). Organisatoriske faktorer som kan bidra til å beholde personalet er godt arbeidsmiljø, fleksibilitet $\mathrm{i}$ arbeidssituasjonen, faglig utvikling, og ledere som er synlige, gir oppmuntrende tilbakemeldinger og lytter til personalet $(4,5,9,10)$. Alle forhold som hindrer direkte utøvelse av pleie til beboerne oppfattes som utilfredsstillende (5). Medvirkende årsaker til at sykepleiere slutter i sykehjem er oftere relatert til organisatoriske forhold enn til at sykepleierne ikke ønsker å arbeide med syke gamle mennesker $(9,10)$. Begrunnelsene sykepleiestudenter gir for ikke å velge arbeid i sykehjem etter endt utdanning er de samme $(11,12)$.

\section{Metode}

Prosjektet er gjennomført i perioden mai-desember 2008. Prosjektet inkluderte tre grupper av sykepleiere: 1) Seks sykepleiere som slut- tet ved sykehjemmet våren 2008, 2) Fire sykepleiere som begynte i sykehjemmet i perioden juni til oktober 2008 og 3) Fire sykepleiere med to års erfaring eller mer fra sykehjemmet. Alle sykepleierne ga informert samtykke. Hvor lang arbeidserfaring sykepleierne hadde før de begynte i sykehjemmet, varierte.

Sykepleierne ble intervjuet individuelt eller i gruppe. Intervjuene varte fra 30 til 60 minutter. Temaene i intervjuene var: Forhold som kunne bidra til å anse sykehjemmet som en fremtidig arbeidsplass, om det å være sykepleier i sykehjemmet og hva de vurderte som sentrale sykepleiefaglige utfordringer. Sykepleierne som hadde sluttet, ble spurt om årsaken til dette. Under de individuelle intervjuene ble det tatt utfyllende notater. Gruppeintervjuene ble tatt opp på bånd og transkribert. Umiddelbart etter alle intervjuene ble hovedinntrykkene beskrevet.

Det ble gjort en tematisk innholdsanalyse av tekstmaterialet. Tekstene ble lest gjentatte ganger og lydopptakene ble lyttet gjennom for å identifisere hovedtemaer (13). Tekstmaterialet ble lest gruppevis og «på tvers» for å identifisere gjennomgående temaer i alle gruppene (5). Gjennom lesningene ble det identifisert ulike subkategorier som videre i analysen ble utviklet til hovedkategoriene som beskrives under.

\section{Resultater}

Et sentralt tema i alle intervjuene var sykepleierrollen i sykehjemmet. En forutsetning for å betrakte sykehjemmet som fremtidig arbeidsplass var en tydeliggjøring og klarere anerkjennelse av sykepleierrollen, samt muligheter for faglig utvikling. Et typisk utsagn var: «Må kjenne at jeg jobber som sykepleier». Sykepleierne beskrev rollen som interessant og utfordrende fordi den innebar mange store faglige utfordringer, stor grad av selvstendighet og stort ansvar. De store faglige utfordringene ble begrunnet med at pasientgruppen (sykehjemmet bruker betegnelsen pasient og ikke beboer) er sammensatt, ofte har flere sykdommer og i mange tilfeller multiorgansvikt. Dette krever at sykepleierne har gode kunnskaper, er gode til å observere, vurdere og ta beslutninger. I tillegg kan samhandlingen med pasienter i sykehjem være utfordrende på grunn av mental svikt og/eller psykiske plager. Et godt klinisk blikk ble derfor vurdert som viktig. Det ble også beskrevet som en utfordring at sykehjemmet skal være pasientenes hjem og at sykepleierne derfor skal bidra til et godt liv og trivsel til tross for pasientenes store helsemessige problemer. 


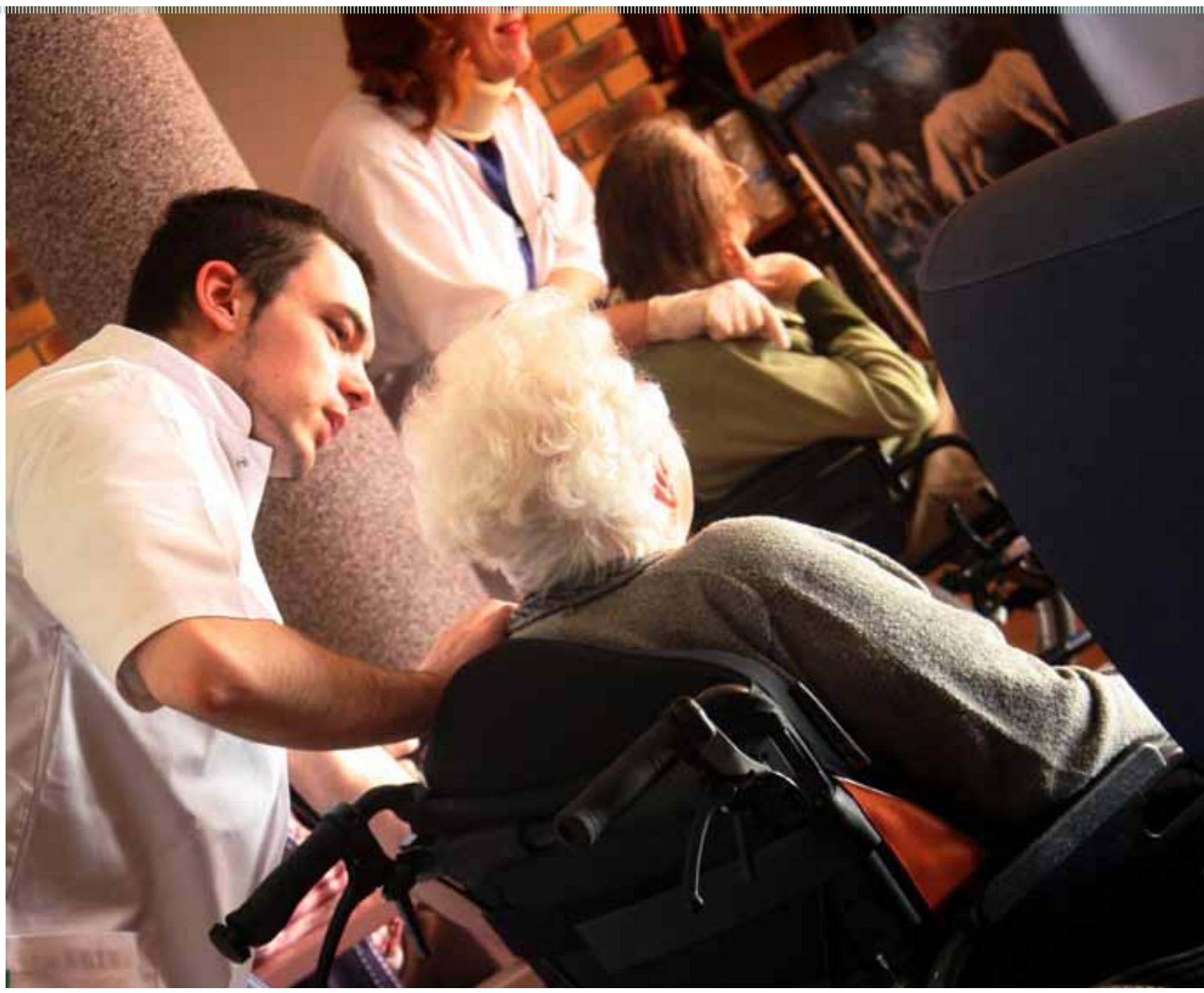

En av sykepleierne sa: «Sykehjem er et sted hvor vi virkelig kan vise hva sykepleie er».

\section{Sykepleiernes erfaringer}

Sykepleierne erfarte imidlertid sykepleierrollen i sykehjemmet som for lite avgrenset. Mange opplevde forventninger fra kollegaer om å delta i alle praktiske gjøremål i avdelingen. For sykepleieren kom dette i tillegg til oppgaver som administrering av medisiner, vur-

FIGUR 1: Innhold i og forutsetninger for en attraktiv sykepleierrolle i sykehjem

\section{Sykepleierrollen i sykehjem:}

) Faglig utfordrende, stor grad av selvstendighet og stort ansvar

- Utfordrende pasientgruppe - multimorbiditet - multiorgansvikt

I Krever gode kunnskaper, evne til å observere, vurdere og ta beslutninger - et godt klinisk blikk

) Utfordrende samspill med pasientene

- Utfordrende at sykehjemmet er pasientenes hjem - bidra til et godt liv og skape trivsel

\section{«Sykehjem - et sted hvor vi virkelig kan vise hva sykepleie er»}

\begin{tabular}{|c|c|c|}
\hline $\begin{array}{l}\text { Tydeliggjøring av } \\
\text { sykepleierrollen: }\end{array}$ & $\begin{array}{l}\text { Anerkjennelse av } \\
\text { sykepleierrollen: }\end{array}$ & $\begin{array}{l}\text { Muligheter for } \\
\text { faglig utvikling: }\end{array}$ \\
\hline $\begin{array}{l}\text { Mer tid til sykepleie- } \\
\text { faglige vurderinger og } \\
\text { dokumentasjon } \\
\text { Rolleavklaring i for- } \\
\text { hold til hjelpepleiere/ } \\
\text { omsorgsarbeidere }\end{array}$ & $\begin{array}{l}\text { Anerkjennelse av } \\
\text { ansvar, oppgaver og } \\
\text { kompetanse } \\
\text { Bli inkludert i vurderinger } \\
\text { i avdelingen } \\
\text { I Forutsigbarhet i ansvar } \\
\text { Lønns-kompensasjon for } \\
\text { ansvarsvakter }\end{array}$ & $\begin{array}{l}\text { Arenaer for faglige } \\
\text { diskusjoner } \\
\text { Faglig miljø på tvers av } \\
\text { avdelingene } \\
\text { Muligheter for kurs og } \\
\text { videre utdanning }\end{array}$ \\
\hline
\end{tabular}

dering av pasienter, sårstell og så videre. Selv om sykepleierne var blitt fortalt at de måtte «trekke seg tilbake» for å fylle dosetter, skrive i pleieplaner eller utføre andre sykepleieoppgaver, opplevde mange sanksjoner når de gjorde dette. Slike erfaringer førte til at sykepleierne deltok på lik linje med de andre i praktiske gjøremål i avdelingen og opplevde dermed å få for liten tid til oppgaver som krevde sykepleiekompetanse.

Sykepleierne beskrev også at det å ha ansvar for andre avdelinger i tillegg til å ha ansvar for en gruppe pasienter på «egen» avdeling kunne være vanskelig. Dersom de ble tilkalt til andre avdelinger, opplevde de å påføre kollegaer merarbeid samt at pasientene ikke ble fulgt opp slik sykepleier mente de hadde behov for. Ansvaret for andre avdelinger skapte også en uforutsigbarhet i arbeidssituasjonen. I tillegg opplevde sykepleierne det som en belastning ikke å vite hvor mange avdelinger de skulle ha ansvar for før de kom på vakt.

De nyansatte sykepleierne og flere av sykepleierne som hadde sluttet, var også opptatt av at institusjonen burde hatt bedre oppfølging av nyansatte. Flere av sykepleierne erfarte at det ofte oppsto uforutsette situasjoner som bidro til at de ikke fikk den opplæring og oppfølging de var forespeilet. De hadde forstå-
KREVENDE ROLLE: Mange sykepleiere opplever at arbeidsoppgavene de har $\mathrm{i}$ sykehjem er for lite avgrenset, slik at det blir for liten tid til spesifikke sykepleieoppgave. Illustrasjonsfoto: Colourbox

\section{Mange av sykepleierne mente de burde fått lønnskompensasjon på vakter hvor de hadde ansvar for flere avdelinger.}


else for at slike situasjoner oppsto, men mente at avdelingsleder i større grad burde fulgt opp sykepleierne i etterkant av slike situasjoner.

Analysen resulterte $\mathrm{i}$ at forutsetningene for en faglig interessant sykepleierrolle ble delt inn i tre hovedkategorier (se figur 1).

\section{Sykepleierrollen}

Alle sykepleierne var opptatt av at de måtte få bedre muligheter til å fokusere på det de oppfattet som sykepleiefaglige oppgaver i avdelingen. De ønsket bedre tid til å vurdere pasientene og deres behov, til å sette seg inn i pasientenes diagnoser og medikamenter og diskutere med sykehjemmets lege. For å få bedre tid til sykepleiefaglige oppgaver, mente sykepleierne det var nødvendig å tydeliggjøre sykepleierrollen i forhold til de øvrige ansatte i avdelingen. En av sykepleierne uttrykte det slik: «Vi har forskjellige stillinger. Og det synes jeg burde tydeliggjøres».

Sykepleierne var opptatt av en tydeligere anerkjennelse av sykepleierens ansvar, oppgaver og kompetanse og at denne i større grad ble brukt. En sa: «At vi blir tatt litt mer på alvor,

\section{Ingen av sykepleierne som oppga pasientene som årsak til at de sluttet i sykehjemmet.}

som sykepleiere.» Sykepleierne beskrev betydningen av å bli sett og hørt av ledelsen - som sykepleiere. For eksempel å få være med å vurdere behovet for kompetanse i avdelingen, særlig på helgevakter. Eller hvor mange sykepleiestudenter avdelingen har kapasitet til å ta imot. I sykehjemmet er det et system for ansvarsvakter hvor sykepleierne har ansvar for flere avdelinger. Sykepleierne anså dette som en stor faglig utfordring, men ønsket større grad av forutsigbarhet med hensyn til hvilke og hvor mange avdelinger de skulle ha ansvar for, kompetansen til personalet på disse avdelingene og nødvendig informasjon om dårlige pasienter. Mange av sykepleierne mente de burde fått lønnskompensasjon på vakter hvor de hadde ansvar for flere avdelinger. De mente dette ville bli oppfattet som en anerkjennelse av det store ansvaret slike vakter innebærer. Sykepleierne mente generelt at høyere lønn ville bidra til å rekruttere og beholde sykepleiere.

\section{Fagutvikling}

Alle sykepleierne mente faglig utvikling var en viktig forutsetning for å fortsette å arbeide i sykehjem. Faglig utvikling kunne skje både internt i sykehjemmet og eksternt gjennom kurs eller videreutdanning. Et sykepleiefaglig miljø på tvers av avdelingene og arenaer for faglige diskusjoner ble beskrevet som attraktivt.
Arbeidsbelastningen måtte ikke være større enn at de faktisk fikk tid til å delta på faglige møter utenfor avdelingen.

Andre faktorer som bidro til at sykepleierne ønsket å fortsette ved sykehjemmet, var pene fysiske omgivelser og godt arbeidsmiljø. Sykehjemmet ble beskrevet som et trivelig sted å arbeide. Ytre faktorer var i liten grad tematisert i intervjuene. En av sykepleierne mente at personalboliger under markedspris ville vært av betydning for å fortsette å arbeide i sykehjemmet.

\section{Diskusjon}

Hovedkonklusjonen var at sykepleierne anså sykepleierrollen i sykehjem som en interessant og utfordrende rolle. Men, som vist i figur 1, tre forutsetninger måtte være til stede for at rollen skulle oppleves slik. I samsvar med tidligere forskning $(9,14)$ var det ingen av sykepleierne som oppga pasientene som årsak til at de sluttet i sykehjemmet.

Sykepleierne opplevde forventninger om å delta i alle typer av oppgaver $i$ avdelingen og erfarte at det ble for liten tid til sykepleiefaglige og medisinske oppgaver. Dette førte til at sykepleierrollen ble for utydelig, et aspekt som er lite fremmet i litteraturen. Behovet for en tydeligere anerkjennelse av sykepleierrollen i sykehjemmet samsvarer med internasjonal forskning om jobbtilfredshet (4). Sykepleiernes behov for faglig utvikling gjennom arenaer for faglige diskusjoner på institusjonen, et sykepleiefaglig miljø på tvers av avdelingene og tilbud om kurs bekreftes i litteraturen. Førland, Haukom og Kristoffersen (15) fant også at faglige utfordringer og kunnskapstilegnelse for å takle komplekse pasientsituasjoner var viktig for sykepleiere og bidro til jobbtrivsel.

I gruppen av sykepleiere som sluttet i sykehjemmet var alle utdannet de siste fem årene, og for fem av seks var sykehjemmet deres første arbeidssted som sykepleier. Dette kan være et uttrykk for at sykehjem, med det store ansvaret det innebærer, er en for stor utfordring for nyutdannede sykepleiere. Men det kan også bunne i at nyutdannede sykepleiere vil ha variert erfaring og derfor ikke forblir i stillinger over lengre tid. Rognstad (16) påpeker dessuten at mange sykepleiestudenter ønsker å ta videreutdanning og spesialisere seg. Dette kan også være en medvirkende årsak til at nyutdannede ikke forblir i sykehjem.

Dette er et avgrenset pilotprosjekt, men kan være et bidrag i videre arbeid med å øke andelen sykepleiere i sykehjem. På bakgrunn av resultatene fra dette prosjektet arbeider sykehjemmet med tiltak som kan være med å understøtte den sykepleierrollen sykepleierne beskrev som utfordrende og spennende, samt å utvikle tiltak som kan gi nyutdannede sykepleiere nødvendig trygghet til å forbli i sykehjemmet.

Prosjektet er delvis finansiert via midler fra undervisningssykehjemmet i Oslo, Abildsø bo- og rehabiliteringssenter. IIII

\begin{tabular}{|c|c|c|c|c|c|c|c|c|c|}
\hline \multicolumn{3}{|c|}{ LITTERATUR } & \multirow{3}{*}{$\begin{array}{l}\text { a qualitative exploration of registered } \\
\text { nurses) experiences working in nursing } \\
\text { homes. International Journal of Older } \\
\text { People Nursing 2007; 2(3): 198-203. }\end{array}$} & \multirow{3}{*}{8.} & \multirow{2}{*}{$\begin{array}{l}\text { long-term care. Health Care Supervisor } \\
\text { 1995; 13(4): 18-28. }\end{array}$} & & \multirow{2}{*}{$\begin{array}{l}\text { nurses to long-term care. Journal of } \\
\text { Gerontological Nursing 1996; 22(9): } \\
\text { 24-32, 54-5. }\end{array}$} & \multirow[t]{2}{*}{14.} & \multirow{2}{*}{$\begin{array}{l}\text { Robertson JF, Cummings CC. Attracting } \\
\text { nurses to long-term care. Journal of } \\
\text { Gerontological Nursing 1996;22(9):24-32. }\end{array}$} \\
\hline 1. & $\begin{array}{l}\text { Bostick JE, et al. Systematic review of } \\
\text { studies of staffing and quality in nursing }\end{array}$ & & & & & & & & \\
\hline & $\begin{array}{l}\text { homes. Journal of the American Medical } \\
\text { Directors Association 2006; } 7(6): 366-76 .\end{array}$ & \multirow{3}{*}{5.} & & & of spirit at work: increasing job & 11. & Bergland A. Lærum H. Hvem vil arbeide & 15. & Kristoffer- \\
\hline \multirow[t]{2}{*}{2.} & $\begin{array}{l}\text { Riggs CJ, Rantz MJ. A model of staff sup- } \\
\text { port to improve retention in long-term }\end{array}$ & & $\begin{array}{l}\text { Moyle W, et al. Views of job satisfaction } \\
\text { and dissatisfaction in Australian long- } \\
\text { term care. Journal of Clinical Nursing }\end{array}$ & & $\begin{array}{l}\text { satisfaction and organizational com- } \\
\text { mitment and reducing turnover and } \\
\text { absenteeism in long-term care. Journal }\end{array}$ & & $\begin{array}{l}\text { med eldre? En undersøkelse blant } \\
\text { norske sykepleiestudenter. Vård i Norden } \\
\text { 1999; 19(3): 4-10. }\end{array}$ & & $\begin{array}{l}\text { sen I. Jobbtilfredshet og jobbtrivsel } \\
\text { blant sykepleiere - refleksjoner og } \\
\text { utfordringer. I: Alvsvåg H, Førland O, red. }\end{array}$ \\
\hline & $\begin{array}{l}\text { care. Nursing Administration Quarterly } \\
\text { 2001; 25(2): 43-54. }\end{array}$ & & $\begin{array}{l}\text { 2003; 12(2): 168-76. } \\
\text { Johannessen A. Recruitment probler }\end{array}$ & & $\begin{array}{l}\text { of Gerontological Nursing 2008; } 34 \\
\text { (10): } 17-25 \text {. }\end{array}$ & 12. & $\begin{array}{l}\text { Bergland } \AA \text {, Lærum H. Norske sykeplei- } \\
\text { estudenters syn på eldreomsorgen som }\end{array}$ & & $\begin{array}{l}\text { Engasjement og læring. Oslo: Akribe, } \\
\text { 2007: 251-268. }\end{array}$ \\
\hline 3. & $\begin{array}{l}\text { Helse- og omsorgsdepartementet, } \\
\text { St.meld. nr. } 25 \text { (2005-2006) Mestring, }\end{array}$ & & $\begin{array}{l}\text { Norwegian nursing homes: experiences } \\
\text { and ideas of registered nurses. Vård i }\end{array}$ & \multirow[t]{2}{*}{9.} & $\begin{array}{l}\text { Flackman B, Sorlie V, Kihlgren M. Unmet } \\
\text { expectations: why nursing home staff }\end{array}$ & & $\begin{array}{l}\text { arbeidsplass etter endt utdanning. Vård i } \\
\text { Norden 2002; 22(2): p. 21-26. }\end{array}$ & \multirow[t]{3}{*}{16.} & \multirow{3}{*}{$\begin{array}{l}\text { Rognstad MK. Det postmoderne sam- } \\
\text { funnets innvirkning på sykepleierrollen. } \\
\text { I: H. Alvsvåg H, Førland O, Red. Engasje- } \\
\text { ment og læring. Fagkritiske perspektiver } \\
\text { på sykepleie. Oslo: Akribe, 2007: 45-61. }\end{array}$} \\
\hline & $\begin{array}{l}\text { muligheter og mening. Framtidas } \\
\text { omsorgsutfordringer. } 2006 \text {. }\end{array}$ & & Norden 2004; 24(4): 45-7. & & $\begin{array}{l}\text { leave care work. International Journal of } \\
\text { Older People Nursing 2008; } 3(1): 55-62 \text {. }\end{array}$ & 13. & Malterud K. Kvalitative metoderi & & \\
\hline 4. & Prentice D, Black M. Coming and staying: & & $\begin{array}{l}\text { Grieshaber LD, Parker P, Deering J. Job } \\
\text { satisfaction of nursing assistants in }\end{array}$ & 10. & & & $\begin{array}{l}\text { medisinsk forskning 2. ed. Usio: Univer- } \\
\text { sitetsforlaget } 2003 \text {. }\end{array}$ & & \\
\hline
\end{tabular}

